\title{
New Nodulation Mutants Responsible for Infection Thread Development in Lotus japonicus
}

\author{
Koji Yano, ${ }^{1}$ Myra L. Tansengco, ${ }^{1}$ Taihei Hio, ${ }^{1}$ Kuniko Higashi, ${ }^{1,2}$ Yoshikatsu Murooka, ${ }^{1}$ \\ Haruko Imaizumi-Anraku, ${ }^{3}$ Masayoshi Kawaguchi, ${ }^{2}$ and Makoto Hayashi ${ }^{1}$ \\ ${ }^{1}$ Department of Biotechnology, Graduate School of Engineering, Osaka University, 2-1 Yamadaoka, Suita, Osaka 565-0871, \\ Japan; ${ }^{2}$ Department of Biological Sciences, Graduate School of Science, The University of Tokyo, 7-3-1 Hongo, Bunkyo, \\ Tokyo 113-0033, Japan; ${ }^{3}$ National Institute of Agrobiological Sciences, 2-1-2 Kannondai, Tsukuba, Ibaraki 305-8602, Japan
}

Submitted 19 September 2005. Accepted 2 January 2006.

\begin{abstract}
Legume plants develop specialized root organs, the nodules, through a symbiotic interaction with rhizobia. The developmental process of nodulation is triggered by the bacterial microsymbiont but regulated systemically by the host legume plants. Using ethylmethane sulfonate mutagenesis as a tool to identify plant genes involved in symbiotic nodule development, we have isolated and analyzed five nodulation mutants, Ljsym 74-3, Ljsym79-2, Ljsym79-3, Ljsym80, and Ljsym82, from the model legume Lotus japonicus. These mutants are defective in developing functional nodules and exhibit nitrogen starvation symptoms after inoculation with Mesorhizobium loti. Detailed observation revealed that infection thread development was aborted in these mutants and the nodules formed were devoid of infected cells. Mapping and complementation tests showed that Ljsym 74-3, and Ljsym 79-2 and Ljsym79-3, were allelic with reported mutants of $L$. japonicus, alb1 and crinkle, respectively. The Ljsym82 mutant is unique among the mutants because the infection thread was aborted early in its development. Ljsym 74-3 and Ljsym80 were characterized as mutants with thick infection threads in short root hairs. Map-based cloning and molecular characterization of these genes will help us understand the genetic mechanism of infection thread development in L. japonicus.
\end{abstract}

Legume plants establish a symbiotic interaction with rhizobia, resulting in the formation of root nodules. In the central nodule tissue, rhizobia fix atmospheric nitrogen to ammonium to be used by the host plants. This legume-rhizobia symbiosis starts with chemical signaling between the host plants and the rhizobia. Rhizobia synthesize Nod factors when they perceive flavonoid compounds released from host plants (Oldroyd and Downie 2004). This results in the curling of growing root hairs which entrap the rhizobia. Infection threads then are developed from the point of curling, allowing the rhizobia to penetrate into the cell. Inside the roots, cortical cells divide to develop nodule primordia. Infection threads elongate toward the nodule

Corresponding author: M. Hayashi; E-mail: Telephone: +49-89-2180-6375; Makoto.Hayashi@1rz.uni-muenchen.de

Current address of M. L. Tansengco: Microbiology \& Genetics Division, Industrial Technology Development Institute, Department of Science \& Technology, Bicutan, Tagig, Metro Manila 1604, Philippines.

Current address of K. Yano and M. Hayashi: University of Munich (LMU), Department of Biology, Genetics, Maria-Ward-Str. 1a, D-80638 München, Germany. primordia by forming a network structure and, finally, rhizobia are released into the host cells (Gage 2004).

Recently, many symbiotic mutants have been isolated from the model legumes Lotus japonicus and Medicago truncatula. Several symbiotic genes have been identified in which mutation causes symbiotic phenotypes, designated non-nodulation ( $\mathrm{Nod}^{-}$ ), nonfixation $\left(\mathrm{Fix}^{-}\right)$, or hypernodulation $\left(\mathrm{Nod}^{++}\right)$. Nod ${ }^{-}$mutants include nin (Schauser et al. 1999), symrk/nork (Endre et al. 2002; Stracke et al. 2002), nfrl and nfr5 (Madsen et al. 2003; Radutoiu et al. 2003), castor (Imaizumi-Anraku et al. 2005), pollux/dmil (Ané et al. 2004; Imaizumi-Anraku et al. 2005), dmi3 (Lévy et al. 2004; Mitra et al. 2004), nspl (Smit et al. 2005), and $n s p 2$ (Kaló et al. 2005). These mutants fail to undergo infection thread initiation and cortical cell division. Except for $\mathrm{nin}$, these mutants also show no root hair curling. The gene has been identified from a Fix ${ }^{-}$mutant, sst 1 (Krusell et al. 2005). Nod $^{++}$mutants represent harl (Krusell et al. 2002; Nishimura et al. 2002a) and astray (Nishimura et al. 2002b). These mutants develop extra nodules compared with the wild-type plants.

To understand the interaction between host plants and rhizobia, it is necessary to reveal not only the early responses to Nod factors but also the succeeding processes of nodule development, including infection thread formation, cortical cell division, and nodule differentiation. Infection threads are very important structures that allow the delivery of rhizobia from the rhizosphere to the host cells. Ardourel and associates (1994) demonstrated that a nodF/nodL double mutant of Sinorhizobium meliloti, which synthesizes Nod factors that lack an Oacetyl group and have a modified $\mathrm{N}$-acyl group, does not induce infection thread formation, although it colonizes curled root hairs of M. truncatula. Limpens and associates (2003) showed that LYK3 and LYK4, LysM domain-containing receptor-like kinases of $M$. truncatula, are important for infection thread development in response to specific Nod factor structures. When they suppressed expression of these genes by RNA interference (RNAi), infection thread elongation was affected by inoculation with a nodFE mutant of $S$. meliloti, which synthesizes Nod factors that have a modified $\mathrm{N}$-acyl group, but not by inoculation with wild-type $S$. meliloti. Pssym35, which has a mutation in the pea Nin gene, induces root hair curling accompanied with colonization of rhizobia, but fails to initiate infection thread formation (Borisov et al. 2003; Tsyganov et al. 1999, 2002). Nin encodes a putative transcriptional regulator (Borisov et al. 2003; Schauser et al. 1999). It is possible that this regulator affects the expression of a set of genes necessary for infection thread initiation. With limited information on how infection threads are initiated at the molecular level, the process of infection thread development is far from clear. To date, several mu- 
tants with aberrant infection thread development have been isolated in L. japonicus and M. truncatula (Bénaben et al. 1995; Imaizumi-Anraku et al. 1997; Kuppusamy et al. 2004; Mitra and Long 2004; Schauser et al. 1998; Tansengco et al. 2003; Veereshlingam et al. 2004). In pea, at least nine loci are responsible for infection thread development (Tsyganov et al. 2002), suggesting that we still can identify novel mutants that show defects in infection thread development. Here, we present the isolation and characterization of five mutant lines, Ljsym743, Ljsym79-2, Ljsym79-3, Ljsym80, and Ljsym82, from the model legume L. japonicus. After detailed analysis of infected roots, we have determined that these mutants are affected at different developmental stages in infection thread development in root hairs. Mapping analysis and complementation tests reveal that three mutants are allelic with known loci. Recent progress on the Lotus genome project will help us to identify genes responsible for infection thread development.

\section{RESULTS}

Isolation of novel symbiotic mutants with incomplete nodule development.

M2 seed of Lotus japonicus B-129 'Gifu' that had been treated with ethylmethane sulfonate (EMS) by Kawaguchi and associates (2002) were screened for nodulation mutants. Preliminary tests on nodulation showed that five lines were candidate mutants with incomplete nodule development. The mutant lines and the wild-type B-129 parent were inoculated with Mesorhizobium loti MAFF303099 and grown under B\&D medium with a low concentration of potassium nitrate (Broughton and Dilworth 1971). After 1 month, all mutant lines were nitrogen starved and growth retarded compared with the wild type (Fig. 1). Under high concentrations of potassium nitrate, mutants appeared to be wild type for growth (data not shown).

\section{Complementation tests.}

Several infection thread mutants have been identified in $L$. japonicus. Ljsym74 (albl) has short, thick infection threads arrested in the epidermis (M. Hayashi, unpublished results). The Ljsym 74 locus is mapped at the northernmost part of the linkage group 1 (Kawaguchi et al. 2005). Ljsym79 (crinkle) shows distortion of segregation, has aborted infection threads in the epidermis, and has crinkled trichomes (Kawaguchi et al. 2002; Tansengco et al. 2003). When trichome development was observed, trichomes of the wild type were straight, whereas those of Ljsym79-3 were crinkled (Fig. 2). The same trichome phenotype was noted in Ljsym79-2 (data not shown). This suggested that both Ljsym79-2 and Ljsym 79-3 were allelic with Ljsym79. From the results of phenotype analysis and mapping (also discussed below), we hypothesized that Ljsym74-3 was an allele of Ljsym 74, and Ljsym79-2 and Ljsym79-3 were alleles of Ljsym79. When Ljsym74-3 was crossed with Ljsym74-1, two pods were harvested after successful crossing. $F_{1}$ progenies (four and two plants from each pod) were used
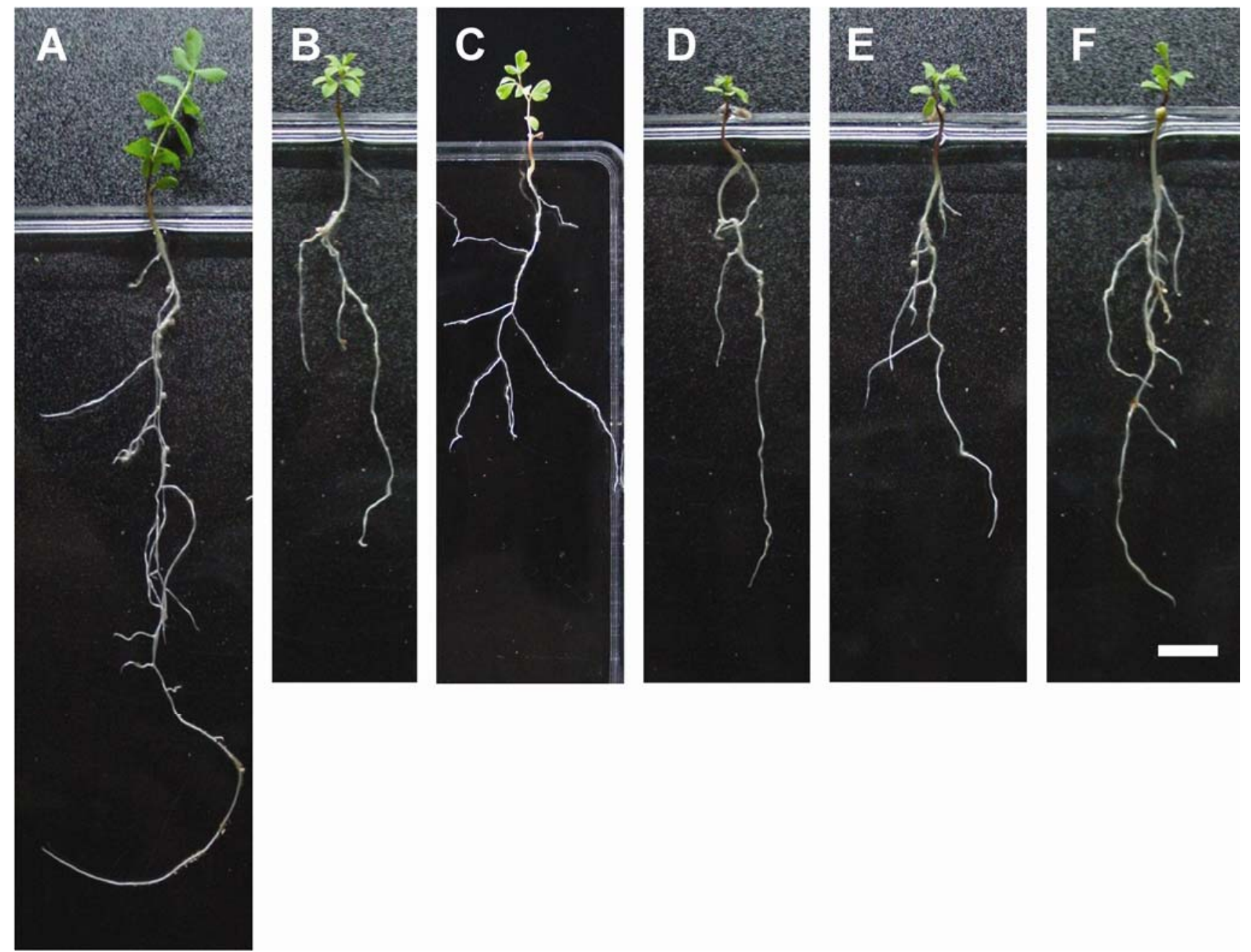

Fig. 1. Growth phenotype of wild type and mutants. Plants were grown for 1 month after inoculation with Mesorhizobium loti MAFF303099. A, Wild type; B, Ljsym74-3; C, Ljsym79-2; D, Ljsym79-3; E, Ljsym80; F, Ljsym82. Bar: $1.0 \mathrm{~cm}$. 
for nodulation assays, and none developed functional nodules. Ljsym79-2 was crossed with Ljsym79 and resulted in five successful crossings. Twenty-five $\mathrm{F}_{1}$ plants (five plants from each pod) were inoculated with rhizobia, and all these plants formed small, white bumps. In addition, the trichome phenotype of the $\mathrm{F}_{1}$ plants was identical with that of Ljsym79. $\mathrm{F}_{1}$ plants (two and three plants from two pods) from the crossing between Ljsym79-3 and Ljsym 79 showed the same phenotype. Because of the results on Ljsym 79 allelism tests, Ljsym 79 is referred to as Ljsym79-1 hereafter.

\section{Segregation and mapping}

\section{of incomplete nodulation mutants in $\mathbf{F}_{\mathbf{2}}$ progenies.}

Segregation of Ljsym74-3, Ljsym79-2, Ljsym79-3, Ljsym80, and Ljsym82 in the $\mathrm{F}_{2}$ progenies from the crosses between each mutant and L. japonicus MG-20 'Miyakojima' was examined. Except for Ljsym79-2 and Ljsym79-3, all mutants showed
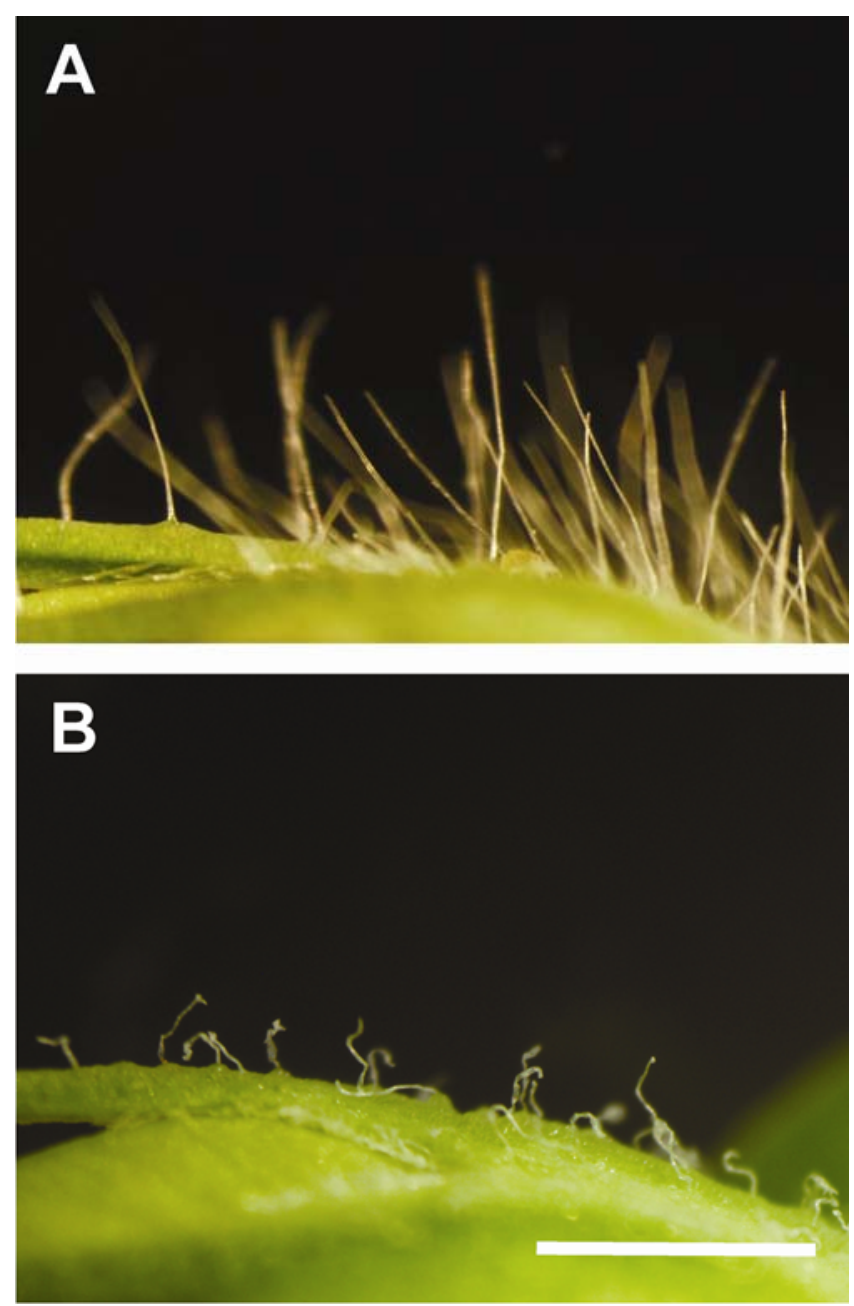

Fig. 2. Trichomes on sepals of wild-type and Ljsym79-3 plants. A, Wild type; B, Ljsym79-3. Bar: $1.0 \mathrm{~mm}$. segregation of wild-type to mutant phenotype as a 3:1 ratio in the $F_{2}$ progeny (Table 1). Cosegregation of the nodule and trichome phenotypes was observed in Ljsym79-2 and Ljsym 79-3, suggesting that these two phenotypes were caused by a single mutation (data not shown). Distortion of segregation observed in Ljsysm79-2 and Ljsym79-3 was described already in Ljsym79-1, possibly due to the male gametophytic deficiency (Tansengco et al. 2004). The distortion of segregation in this region was not markedly observed in a B-129 $\times$ MG-20 cross (Hayashi et al. 2001). $F_{2}$ populations were then utilized for low-resolution mapping using simple-sequence-length polymorphism (SSLP) markers. Ljsym 74-3 was mapped at the northernmost locus of the linkage group 1 , where a suppression of recombination was observed (Fig. 3) (Hayashi et al. 2001). Ljsym80 was mapped between TM0122 and TM0105 on linkage group 1. Ljsym82 was mapped between TM0076 and TM0021 on linkage group 2. Finally, Ljsym79-2 and Ljsym79-3 loci were mapped between TM0151 and TM0024 on linkage group 5.

\section{Nodule structure}

of $\operatorname{Ljsym} 74-3, \operatorname{LjSym} 79-3, \operatorname{LjSym} 80$, and Ljsym82.

Because all mutant lines examined above showed typical nitrogen-starvation symptoms after inoculation with $M$. loti, detailed analysis of nodule structure was done. Ljsym79-2 was omitted from the examination because it was allelic with Ljsym79-3. One month after inoculation with $M$. loti MAFF303099, all mutants formed many bumps, but failed to develop mature nodules (Fig. 4). To examine whether rhizobia were released in the cells of the central nodule tissue, semithin sections of nodules were prepared. In the wild type, many infected cells were observed in the central nodule tissue (Fig. 5A). In all four mutants, however, infected cells were never observed (Fig. 5B through E). After longer incubation in all mutants except in Ljsym82, there were sporadic release events in some parts of the nodules, especially in Ljsym80 (Fig. 5F). This phenotype has been described previously as type II nodules (Imaizumi-Anraku et al. 1997; Tansengco et al. 2003). The above results led us to investigate whether infection thread development was affected in Ljsym74-3, Ljsym79-3, Ljsym80, and Ljsym82.

\section{Abortion of infection thread development in Ljsym 74-3, Ljsym 79-3, Ljsym80, and Ljsym82.}

To visualize infection thread development, Ljsym74-3, Ljsym 79-3, Ljsym80, and Ljsym82 were inoculated with M. loti ML001 carrying a $l a c Z$ reporter gene. Two weeks after inoculation, $\beta$-galactosidase activity was assayed. The wild-type B129 showed typical infection thread development and successful invasion of rhizobia in the inner nodule tissue based on the presence of blue staining (Fig. 6A). In contrast, mutant nodules failed to exhibit visible staining, suggesting the absence of invasion process due to aborted infection threads in the epidermis (Fig. 6B through D). In Ljsym82, two types of infection thread abortion were observed. One abortion was at the initiation, where rhizobia failed to enter into the root hair cells, although rhizobia colonized inside the curled tip of root hairs (Fig. 6E). The second point of arrest was during elongation,

Table 1. Segregation of mutant phenotypes in the $\mathrm{F}_{2}$ progeny of crosses between mutants and MG-20

\begin{tabular}{llccc}
\hline Line & Locus & F $_{\mathbf{2}}$ progeny & Wild-type phenotype & Mutant phenotype \\
\hline S64 & Ljsym74-3 & 182 & 143 & 39 \\
S66 & Ljsym79-2 & 112 & 104 & 8 \\
1-5A & Ljsym79-3 & 100 & 91 & 1.24 \\
N2 & Ljsym80 & 156 & 116 & 9 \\
N4 & Ljsym82 & 158 & 111 & 40 \\
\hline
\end{tabular}

${ }^{a} P>0.05$ when $\chi^{2}<3.84$. 


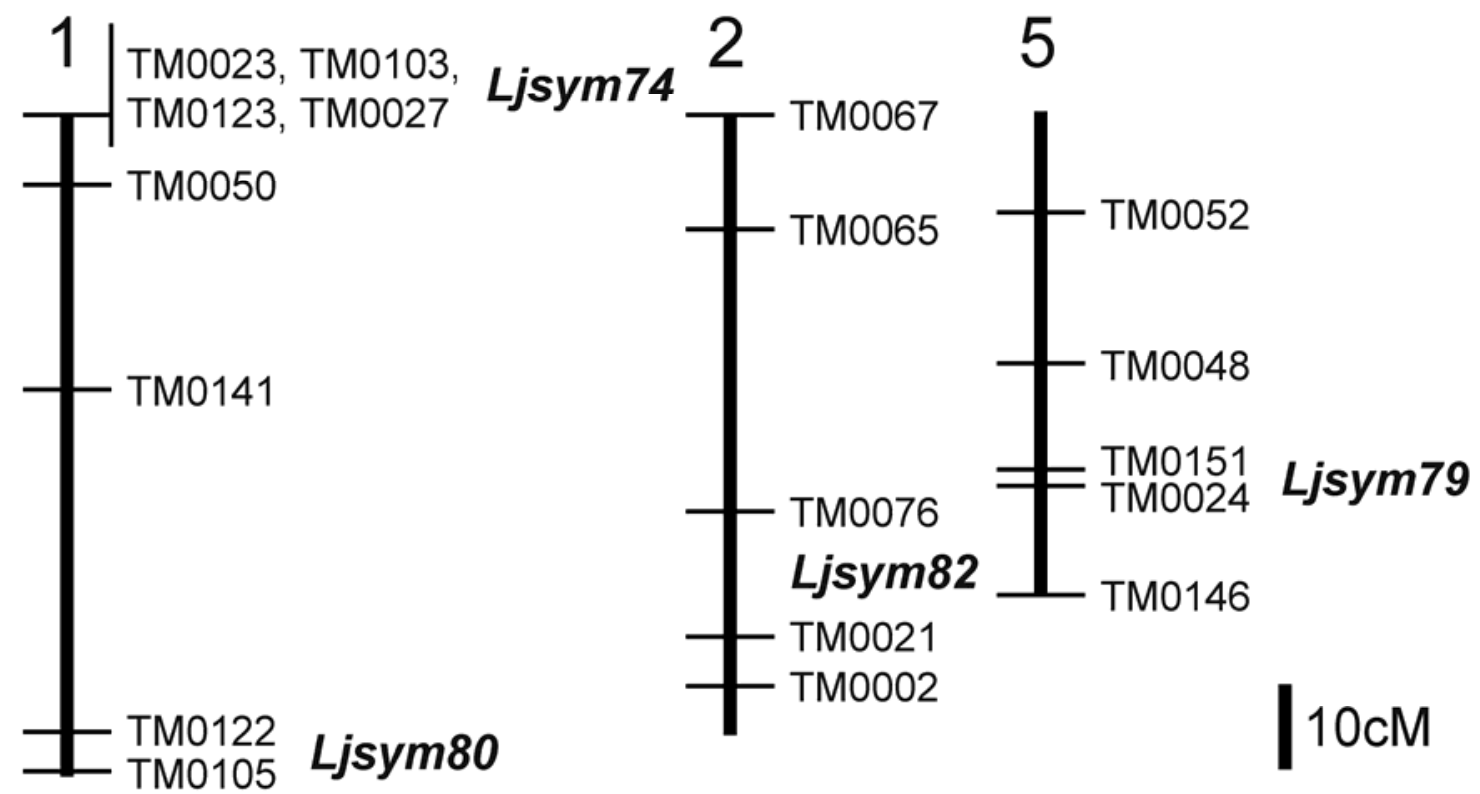

Fig. 3. Mapping of infection thread mutations. Mutant loci were mapped using simple-sequence-length polymorphism markers. The map is based on that of Lotus japonicus MG-20 'Miyakojima'.
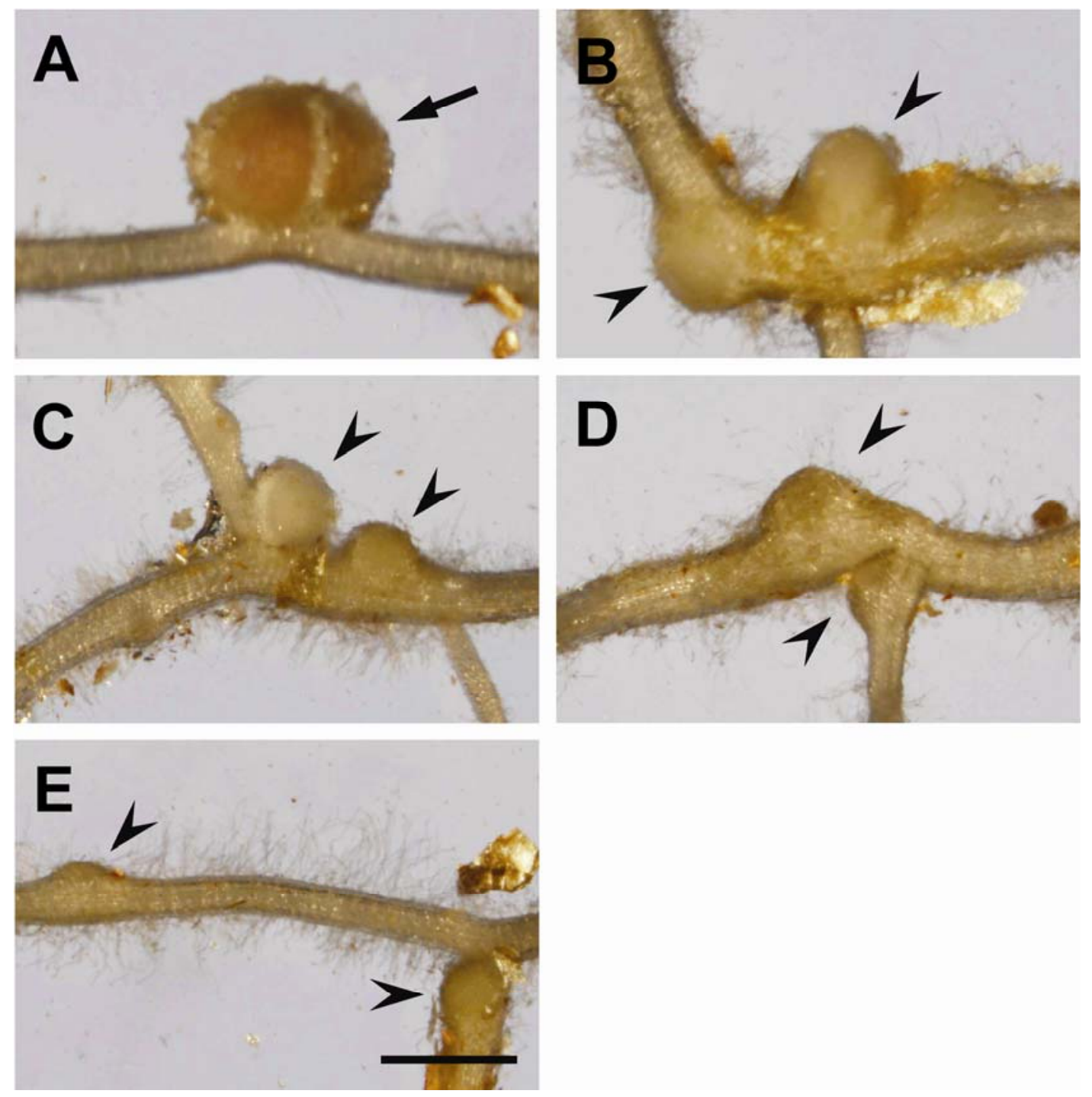

Fig. 4. Nodulation phenotype of wild-type and mutant plants. Plants were grown for 1 month after inoculation with Mesorhizobium loti MAFF303099. A, Wild type; B, Ljsym74-3; C, Ljsym79-3; D, Ljsym80; E, Ljsym82. Arrow indicates nodule. Arrowheads indicate bumps. Bars: $1.0 \mathrm{~mm}$. 
when infection threads stopped at the middle of the root hair cell (Fig. 6F). The morphological phenotype of infected root hairs of Ljsym74-3, Ljsym79-3, and Ljsym80 was compared with the wild type. Mutant Ljsym79-3 had infected root hairs similar to that of the wild type (Fig. 6C); however, Ljsym74-3 and Ljsym80 typically showed short infected root hairs with thick infection threads inside (Fig. 6B and D).

\section{Numbers of nodules and infection threads}

in Ljsym 74-3, Ljsym 79-3, and Ljsym80.

At 2 to 3 weeks after inoculation with M. loti ML001, the total number of nodules and bumps and the number of infec- tion threads were examined (Table 2). To avoid contamination, plants were grown in glass bottles. We were unable to grow Ljsym 82 plants under these conditions, possibly because of the presence of high humidity in the bottles. Two weeks after inoculation with $M$. loti, no significant difference in the total number of nodules and bumps was noted between the wildtype and the mutants. However, 3 weeks after inoculation, the total number of nodules and bumps in Ljsym74-3 and Ljsym 79-3 were 2 and 1.6 times greater than in the wild-type plants, respectively. For the number of infection threads 3 weeks after inoculation, Ljsym79-3 and Ljsym80 were 60 and $40 \%$, respectively, less than in the wild-type plants.
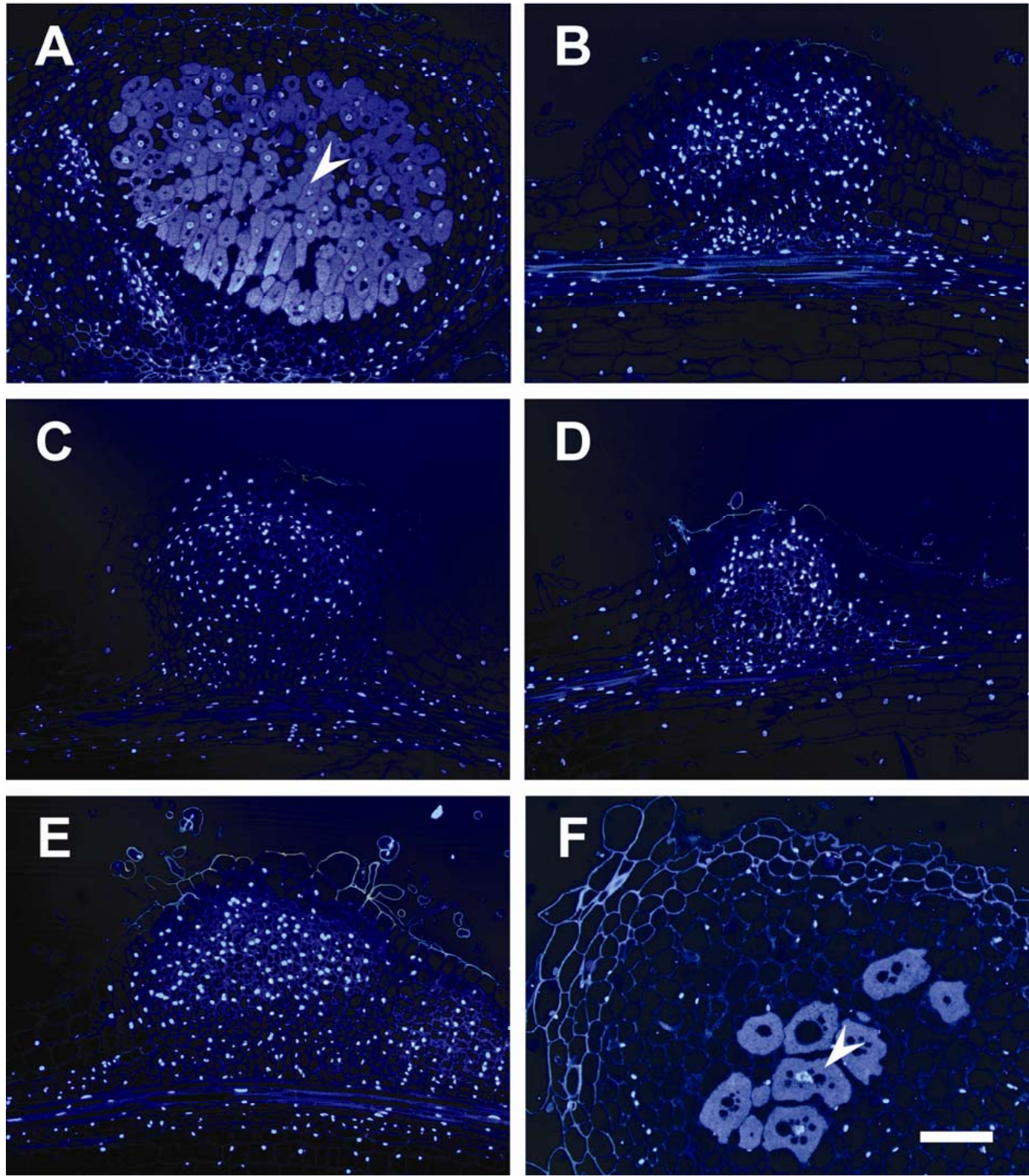

Fig. 5. Histological examination of wild-type and mutant nodules. Plants were grown for 1 month after inoculation with Mesorhizobium loti MAFF303099, except F, which was grown for 2 months after inoculation. Nodules were fixed and embedded in Histo-Technovit 7100. Sections were stained with 4',6-diamidino-2-phenylindole (for nuclei) and fluorescent brightener 28 (for cell wall). A, Developing nodule of the wild type; B, Ljsym74-3; C, Ljsym 79-3; D, Ljsym 80; E, Ljsym82; F, a type II nodule of Ljsym80. Arrowheads indicate infected cells. Bar: $100 \mu \mathrm{m}$. 


\section{DISCUSSION}

We have isolated novel symbiotic mutants from the model legume L. japonicus. These mutants formed small, white bumps that failed to develop into mature nodules (Fig. 4). When semithin sections of nodules were examined, no infected cells were observed in these mutants (Fig. 5). Detailed analysis showed that development of incomplete nodules lacking infected cells was correlated closely with abnormal development of infection threads (Fig. 6). From the results of mapping and complementation tests, we have identified Ljsym74-3, Ljsym79-2, Ljsym79-3, Ljsym80, and Ljsym82 (Fig. 3; Table 1). Three of these mutants are allelic with previously reported mutants of $L$. japonicus (Imaizumi-Anraku et al. 1997; Tansengco et al. 2003), but two mutants, Ljsym80 and Ljsym82, have never been characterized in detail. Previously, several other mutants of L. japonicus have been isolated that formed small, white bumps (Schauser et al. 1998; Szczyglowski et al. 1998). It is
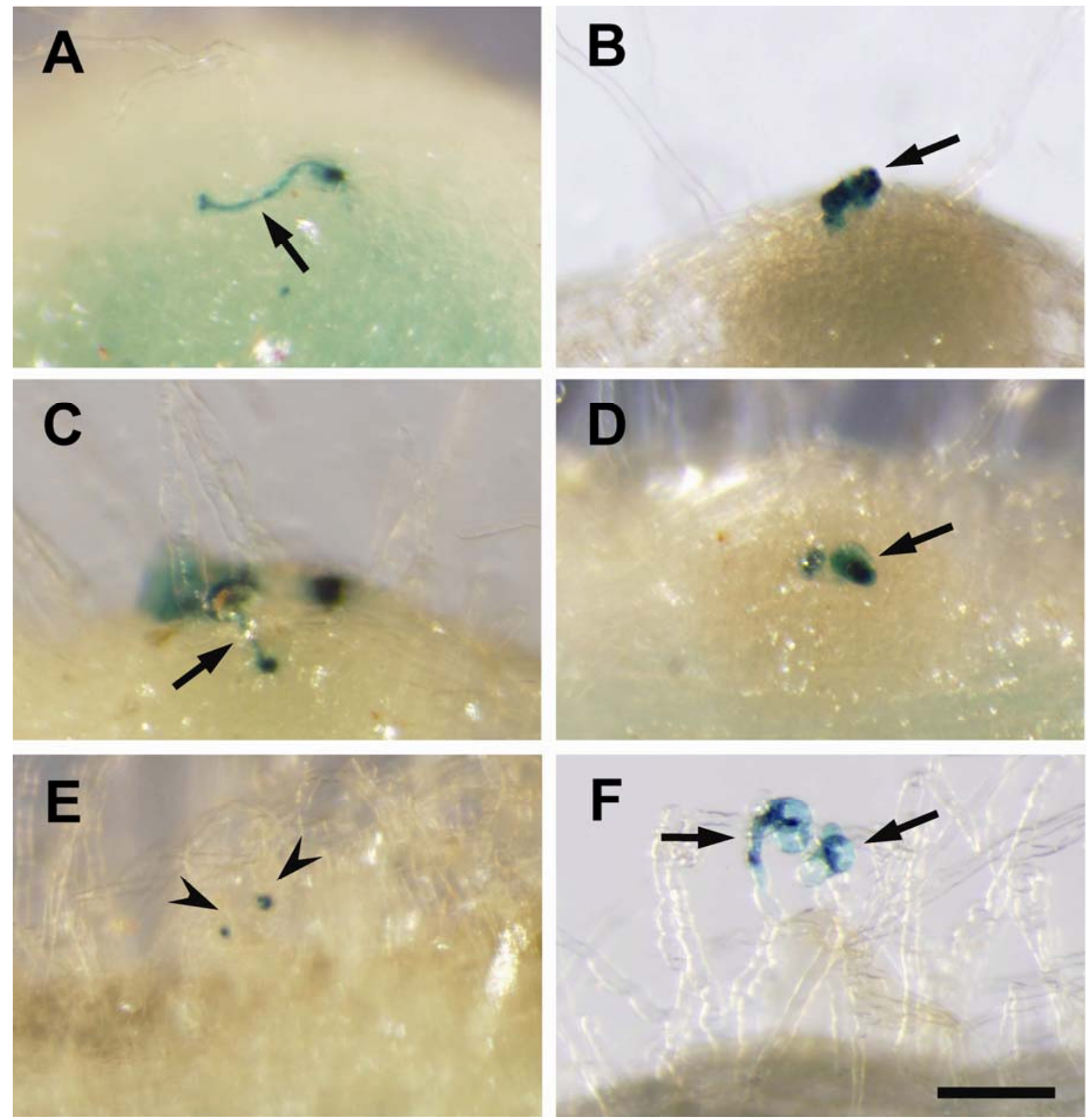

Fig. 6. Development of infection threads in wild-type and mutant plants. Plants were grown for 2 weeks after inoculation with Mesorhizobium loti ML001. A, Wild type; B, Ljsym74-3; C, Ljsym79-3; D, Ljsym80; E, arrest of infection thread initiation in Ljsym82; $\mathbf{F}$, arrest of infection thread elongation in a root hair cell of $L j s y m 82$. Arrows indicate infection threads. Arrowheads indicate colonized rhizobia. Bar: $100 \mu \mathrm{m}$.

Table 2. Number of nodules, bumps, and infection threads in wild-type and mutant plants 2 and 3 weeks after inoculation with Mesorhizobium loti ML001 ${ }^{\mathrm{a}}$

\begin{tabular}{|c|c|c|c|c|c|c|c|c|c|c|}
\hline \multirow[b]{2}{*}{ Plants } & \multicolumn{2}{|c|}{ Plants tested } & \multicolumn{2}{|c|}{ Nodules } & \multicolumn{2}{|c|}{ Bumps } & \multicolumn{2}{|c|}{ Total } & \multicolumn{2}{|c|}{ Infection threads } \\
\hline & 2 & 3 & 2 & 3 & 2 & 3 & 2 & 3 & 2 & 3 \\
\hline Wild-type & 8 & 7 & $2.0 \pm 0.76$ & $3.9 \pm 0.78$ & $1.3 \pm 1.28$ & $1.1 \pm 0.90$ & $3.3 \pm 1.04$ & $5.0 \pm 0.82$ & $35.1 \pm 6.29$ & $52.1 \pm 4.45$ \\
\hline Ljsym74-3 & 6 & 7 & 0 & 0 & $4.5 \pm 1.52$ & $10.7 \pm 2.29$ & $4.5 \pm 1.52$ & $10.7 \pm 2.29$ & $26.3 \pm 4.72$ & $46.9 \pm 5.61$ \\
\hline Ljsym79-3 & 7 & 6 & 0 & 0 & $3.1 \pm 1.21$ & $8.0 \pm 1.41$ & $3.1 \pm 1.21$ & $8.0 \pm 1.41$ & $11.3 \pm 2.50$ & $19.5 \pm 4.32$ \\
\hline Ljsym80 & 6 & 5 & 0 & 0 & $2.5 \pm 0.84$ & $6.0 \pm 2.23$ & $2.5 \pm 0.84$ & $6.0 \pm 2.23$ & $14.7 \pm 2.25$ & $31.0 \pm 7.48$ \\
\hline
\end{tabular}

${ }^{\text {a }}$ Numbers shown at 2 and 3 weeks after inoculation. 
possible that incomplete nodule development in these mutants is influenced by the abortion of infection thread formation, as shown in the mutants we have identified here. Schauser and associates (1998) reported one example of such phenotype in Ljsym 8 mutant.

\section{Initiation of infection thread development.}

In a new mutant, Ljsym82, cortical cell division was initiated, although infection thread development was arrested at the early stage (Fig. 6E and F). Nodule primordia of Ljsym82 also failed to develop into mature nodules (Figs. 4E and 5E). A similar mutant of Medicago truncatula, lin, also initiates cortical cell division with arrested infection thread initiation at the epidermis (Kuppusamy et al. 2004). Recently, the macrosynteny between L. japonicus and M. truncatula was investigated (Choi et al. 2004). Ljsym82 locus is mapped between TM0076 and TM0021 on linkage group 2 (Fig. 6). This region is conserved with linkage group 5 of $M$. truncatula. On the other hand, the LIN locus is located on linkage group 1 of $M$. truncatula (Kuppusamy et al. 2004). This fact suggests that the gene responsible for Ljsym82 is different from the LIN gene. Furthermore, Ljsym 82 fails to establish a symbiosis with arbuscular mycorrhizal fungi; arbuscules develop poorly in the cortical cells (K. Senoo, personal communication). Recently, it has been reported that Ljsym82 is allelic with Ljsym6 (Sandal et al. 2006). The mutant Ljsym6 shows a symbiotic phenotype with incomplete nodule development and almost no arbuscle formation, which is similar to that of Ljsym82 (Kistner et al. 2005). There are two candidates for the Ljsym82 ortholog in pea. One is Pssym14, which shows abortion in the infection thread initiation and weak colonization of arbuscular mycorrhizal fungi (Tsyganov et al. 1999). The other is Pssym36, which shows aberrant development of infection threads before reaching the bottom of epidermal cells (corresponding to DK24 reported by Sagan and associates [1994]), and loss of arbuscule development (corresponding to RisNod24 in Gianinazzi-Pearson 1996). Because Pssym14 does not show any cortical cell division, whereas Pssym36 develops nodule primordia (Tsyganov et al. 2002), Pssym36 is a more likely candidate for Ljsym82 ortholog. Still, there is a possibility that this phenotype is determined by the plant species (i.e., pea or L. japonicus).

\section{Pleiotropic phenotype of $\operatorname{Ljsym} 79$.}

Ljsym79-2 and Ljsym79-3 exhibited not only arrested infection threads but also crinkled trichomes and distorted segregation in the $\mathrm{F}_{2}$ progenies (Figs. 6C and 2B; Table 1). Distorted segregation in nodulation mutants has been reported in a pea mutant, Pssym40, which shows hypertrophied infection threads and abnormal endocytosis of bacteria (Tsyganov et al. 1998). Because $\operatorname{Ljsym} 79$, as well as $\operatorname{Ljsym} 74$, shows hypertrophied infection threads with incomplete nodules (Imaizumi-Anraku et al. 1997; Tansengco et al. 2003), Pssym 40 is a potential candidate for the Ljsym79 ortholog, although its trichome phenotype has not been reported. In addition, the primary nodulation phenotype of Ljsym 79, which is the abortion of infection threads in the epidermis, is not observed in Pssym40. Arrest of infection thread development in the epidermis without accompanying cortical cell division is a typical phenomenon in the wild-type $L$. japonicus (M. Hayashi, unpublished results). However, in Ljsym74, Ljsym79, and Ljsym80, aborted infection threads are observed with nodule primordia. It is possible that aborted infection threads sometimes are incorporated in nodule tissue, which resulted in the formation of hypertrophied infection threads in a later stage of nodule development. This is in accordance with the observation of two types of nodules in these mutants (Fig. 5F) (Imaizumi-Anraku et al. 1997; Tansengco et al. 2003). Abortion of infection thread development in such mutants is supposed to be leaky, occasionally giving rise to a limited number of infected cells. Two types of nodules are also identified in the mutants of pea (Novák et al. 1995; Tsyganov et al. 1998) and M. truncatula (Bénaben et al. 1995).

\section{Suppression of recombination in Ljsym 74 locus.}

Ljsym 74 was mapped at the northernmost locus of the linkage group 1 (Fig. 3). This is the region with a severe degree of recombination suppression, probably caused by a translocation of a chromosome segment between L. japonicus B-129 'Gifu' and MG-20 'Miyakojima' (Hayashi et al. 2001). Therefore, we need crossing partners other than MG-20 to perform positional cloning of Ljsym74. Recently, L. burttii and L. filicaulis were reported as alternative crossing partners to MG-20 (Kawaguchi et al. 2005; Sandal et al. 2002, 2006). The severe suppression of recombination in this region was not observed when they were crossed with L. japonicus B-129 'Gifu' (Kawaguchi et al. 2005; Sandal et al. 2002). Preliminary data indicate that crossing Ljsym74-3 and L. burttii resulted in a good recombination in this region.

\section{Development of infection threads.}

We have shown that infection thread development in Ljsym 743, Ljsym79-3, and Ljsym80 were arrested in the epidermal cells (Fig. 6B through D). This result suggests that the invasion of infection threads from the epidermal cell to the outermost cortical cell is tightly regulated. The morphology of infection threads in Ljsym79-3 seems not to be affected by the mutation because infected root hairs of Ljsym79-3 appeared to be wild type (Fig. 6C). Ljsym74-3 and Ljsym80 have short infected root hairs with thick infection threads compared with the wild type (Fig. 6B and D). Infection threads of $L$. japonicus often develop in elongated root hairs (Szczyglowki et al. 1998). This phenotype also is observed in white clover (Callaham and Torrey 1981) but not in soybean, wherein infection threads develop in short root hairs (Turgeon and Bauer 1982). We hypothesize that genes responsible for developing infection threads or curling of root-hair tips in developing root hairs are affected in Ljsym 74 and Ljsym80. It is interesting to note that infected root hairs in these mutants often are accompanied by thick infection threads which occupy almost the whole diameter of the root hair cell. A similar phenomenon of infection thread development has been observed in Pssym43 (Sagan et al. 1994).

\section{Autoregulation \\ of nodule and infection thread development.}

Three weeks after inoculation with Mesorhizobium loti ML001, the number of bumps in Ljsym80 was similar to the total number of nodules and bumps in the wild type (Table 2). However, the number of bumps in Ljsym74-3 and Ljsym79-3 was significantly higher than that of nodules and bumps in the wild type (Table 2). This is possibly caused by autoregulation of nodulation, which is affected to a certain degree by Nod factors (van Brussel et al. 2002). Developed nodules are already present 3 weeks after inoculation, and also may trigger autoregulation of nodulation (Caetano-Anollés et al. 1991; Nutman 1952). It is possible that autoregulation triggered by Nod factors is effective in Ljsym74-3 and Ljsym79-3 but not that triggered by mature nodules. Thus, these two mutants developed more nodules than wild-type but less than harl mutants (Kawaguchi et al. 2002; Wopereis et al. 2000). Autoregulation is also applicable to infection thread development (Vasse et al. 1993). Three weeks after inoculation with $M$. loti ML001, the number of infection threads in all mutants, except in Ljsym79-3, was comparable with the wild type (Table 2). This result indicates that autoregulation of infection thread development is not affected in such mutants. Fewer infection threads in Ljsym79-3 
possibly are caused by the aberrant development of root hairs, as shown in crinkle mutant (Tansengco et al. 2003)

\section{Position of infection thread mutants}

vis-à-vis symbiotic signal transduction pathway.

In summary, we suggest that genes responsible for $L j s y m 74$, Ljsym79, Ljsym80, and Ljsym82 function downstream of Nin because all these mutants show a certain degree of nodule development. From the cytological observation among the mutants, the gene mutated in Ljsym82 acts earliest in infection thread development because arrest of infection thread initiation was observed only in this mutant. The genes that are involved in fixation, LjSstl and $L j L b$ (symbiotic leghemoglobin genes), are responsible for later stages, because infected cells are observed in plants generated by either mutation or knockdown (Krusell et al. 2005; Ott et al. 2005). Map-based cloning and molecular characterization of these genes will help to clarify the genetic mechanism of infection thread development in L. japonicus.

\section{MATERIALS AND METHODS}

\section{Plant materials and bacterial strains.}

Mutant lines S64 (Ljsym74-3), S66 (Ljsym79-2), 1-5A (Ljsym79-3), N2 (Ljsym80), and N4 (Ljsym82) were isolated from M2 seed of L. japonicus B-129 'Gifu' treated with EMS by Kawaguchi and associates (2002). Plant lines in the M6 generation were used for further phenotypic characterization. All mutant and wild-type seed were scarified with sandpaper, sterilized with $10 \% \mathrm{NaClO}$ for $10 \mathrm{~min}$, washed three times with sterile water, and kept in sterile water for 6 to $8 \mathrm{~h}$. Imbibed seeds were germinated on $1.0 \%$ agar plates and incubated with shading under a cycle of $16 \mathrm{~h}$ at $26^{\circ} \mathrm{C}$ and $8 \mathrm{~h}$ at $23^{\circ} \mathrm{C}$ in a growth cabinet (LPH-350S; Nippon Medical and Chemical Instruments, Osaka, Japan). Three-day-old seedlings were used for each experiment.

Mesorhizobium loti MAFF303099 was obtained from the Ministry of Agriculture, Forestry and Fisheries, National Institute of Agrobiological Sciences, Japan. M. loti MAFF303099 derivative ML001 carrying pGD499 constitutively expressed a lacZ reporter gene (Nukui et al. 2004). Rhizobia were cultured at $28^{\circ} \mathrm{C}$ in tryptone-yeast extract medium with phosphomycin at $100 \mu \mathrm{g} / \mathrm{ml}$ for $M$. loti MAFF303099 and tetracycline at 15 $\mu \mathrm{g} / \mathrm{ml}$ for $M$. loti ML001.

\section{Investigation of nodule structure.}

Seedlings of mutants and the wild type were transferred to pots containing vermiculite supplied with nitrogen-free B\&D medium (Broughton and Dilworth 1971) and $10 \mu \mathrm{M}$ potassium nitrate. Seedlings were inoculated with $M$. loti MAFF303099 and grown under a cycle of $16 \mathrm{~h}$ of light at $26^{\circ} \mathrm{C}$ and $8 \mathrm{~h}$ of dark at $23^{\circ} \mathrm{C}$ in the growth cabinet. After 1 month, nodules were observed under a SZX12 microscope (Olympus, Tokyo). Nodules were subsequently excised and embedded in HistoTechnovit 7100 (Kulzer, Wehrheim, Germany). Fixation, dehydration, and embedding were carried out as previously described by Tansengco and associates (2003). Semithin 2- $\mu$ m sections were prepared at using a glass knife with an Ultracut S microtome (Leica, Deerfield, IL, U.S.A.). Sections were stained with a solution consisting of 4',6-diamidino-2-phenylindole at $10 \mu \mathrm{g} / \mathrm{ml}$ and fluorescent brightener 28 at $5 \mu \mathrm{g} / \mathrm{ml}$ (SigmaAldrich, St. Louis). Thin sections were observed under a BX50 microscope (Olympus).

\section{Examination of $\beta$-galactosidase activity in infection threads.}

Seedlings of mutants and the wild type were transferred to pots or 500-ml glass bottles containing vermiculite:perlite mix
(5:1, wt/vol) supplied with B\&D medium and $10 \mu \mathrm{M}$ potassium nitrate. M. loti ML001 at a cell density of $10^{8}$ cells $/ \mathrm{ml}$ was inoculated. The plants were grown under $16 \mathrm{~h}$ of light at $26^{\circ} \mathrm{C}$ and $8 \mathrm{~h}$ of dark at $23^{\circ} \mathrm{C}$ in a growth cabinet. After 2 or 3 weeks, roots were vacuum infiltrated for $20 \mathrm{~min}$ with fixative solution $(2 \%$ [vol/vol] glutaraldehyde in $1 \times$ phosphate-buffered saline [PBS], $\mathrm{pH} 7.5)$ and incubated for $1 \mathrm{~h}$ at $37^{\circ} \mathrm{C}$. Fixed samples were washed three times with PBS and stained for $\beta$ galactosidase activity using a solution containing $0.2 \times$ PBS (pH 7.5), X-gal at $0.8 \mathrm{mg} / \mathrm{ml}, 2.5 \mathrm{mM} \mathrm{K}_{3}\left[\mathrm{Fe}(\mathrm{CN})_{6}\right], 2.5 \mathrm{mM}$ $\mathrm{K}_{4}\left[\mathrm{Fe}(\mathrm{CN})_{6}\right]$, and 5-bromo-4-chloro-3-indolyl- $\beta$-D-galactoside at $0.8 \mathrm{mg} / \mathrm{ml}$ (Nacalai Tesque, Kyoto, Japan). After $20 \mathrm{~min}$ of vacuum infiltration, samples were incubated overnight at room temperature in the staining solution. Infection threads were observed under an SZX12 microscope.

\section{Mapping.}

Low-resolution mapping was performed using the $\mathrm{F}_{2}$ progeny resulting from crosses between each mutant and L. japonicus MG-20 'Miyakojima' (Kawaguchi et al. 2001). $\mathrm{F}_{2}$ progenies were inoculated with M. loti MAFF303099 and grown in the modified pillow system (Tansengco et al. 2003) supplied with B\&D medium and $10 \mu \mathrm{M}$ potassium nitrate. After approximately 2 months, each plant was scored as either wild type or mutant based on the nodulation phenotype. Low-resolution mapping was carried out with SSLP markers as described previously (Nakamura et al. 2002; Sato et al. 2001). Marker fragments were amplified at $94^{\circ} \mathrm{C}$ for $5 \mathrm{~min}$; followed by 45 cycles of $94^{\circ} \mathrm{C}$ for $50 \mathrm{~s}, 55^{\circ} \mathrm{C}$ for $30 \mathrm{~s}$, and $72^{\circ} \mathrm{C}$ for $1 \mathrm{~min}$; and, finally, $72^{\circ} \mathrm{C}$ for $10 \mathrm{~min}$ with GeneAmp PCR System 9700 (Applied Biosystems, Foster City, CA, U.S.A.). Polymerase chain reaction (PCR) products were subjected to gel electrophoresis in 13\% native polyacrylamide, 3\% NuSieve 3:1 agarose (Cambrex, Rockland, ME, U.S.A.), or 3\% MetaPhor agarose (Cambrex).

\section{ACKNOWLEDGMENTS}

This work was supported by the CREST Program from the Japan Science and Technology Agency to H. Imaizumi-Anraku, M. Kkawaguchi, and M. Hayashi. We thank T. Maekawa for his valuable help in infection thread observation and E. Kobayashi for crossing of mutant lines. We are grateful to J. M. Harris for critical reading of the manuscript. We are also very grateful to K. Senoo for kindly providing us with unpublished results.

\section{LITERATURE CITED}

Ané, J.-M., Kiss, G. B., Riely, B. K., Penmetsa, R. V., Oldroyd, G. E., Ayax, C., Lévy, J., Debellé, F., Baek, J.-M., Kalo, P., Rosenberg, C., Roe, B. A., Long, S. R., Dénarié, J., and Cook, D. R. 2004. Medicago truncatula DMI1 required for bacterial and fungal symbioses in legumes. Science 303:1364-1367.

Ardourel, M., Demont, N., Debellé, F., Maillet, F., de Billy, F., Promé, J. C., Dénarié, J., and Truchet, G. 1994. Rhizobium meliloti lipooligosaccharide nodulation factors: Different structural requirements for bacterial entry into target root hair cells and induction of plant symbiotic developmental responses. Plant Cell 6:1357-1374.

Bénaben, V., Duc, G., Lefebvre, V., and Huguet, T. 1995. TE7, an inefficient symbiotic mutant of Medicago truncatula Gaertn. cv. Jemalong. Plant Physiol. 107:53-62.

Borisov, A. Y., Madsen, L. H., Tsyganov, V. E., Umehara, Y., Voroshilova, V. A., Batagov, A. O., Sandal, N., Mortensen, A., Schauser, L., Ellis, N., Tikhonovich, I. A., and Stougaard, J. 2003. The Sym35 gene required for root nodule development in pea is an ortholog of Nin from Lotus japonicus. Plant Physiol. 131:1009-1017.

Broughton, W. J., and Dilworth, M. J. 1971. Control of leghaemoglobin synthesis in snake beans. Biochem. J. 125:1075-1080.

Caetano-Anollés, G., Paparozzi, E. T., and Gresshoff, P. M. 1991. Mature nodules and root tips control nodulation in soybean. J. Plant Physiol. 137:389-396.

Callaham, D. A., and Torrey, J. G. 1981. The structural basis for infection of root hairs of Trifolium repens by Rhizobium. Can. J. Bot. 59:16471664 
Choi, H.-K., Mun, J.-H., Kim, D.-J., Zhu, H., Baek, J.-M., Mudge, J., Roe, B., Ellis, N., Doyle, J., Kiss, G. B., Young, N. D., and Cook, D. R. 2004. Estimating genome conservation between crop and model legume species. Proc. Natl Acad. Sci. U.S.A. 101:15289-15294.

Endre, G., Kereszt, A., Kevei, Z., Mihacea, S., Kaló, P., and Kiss, G. B. 2002. A receptor kinase gene regulating symbiotic nodule development. Nature 417:962-966.

Gage, D. J. 2004. Infection and invasion of roots by symbiotic, nitrogenfixing rhizobia during nodulation of temperate legumes. Microbiol. Mol. Biol. Rev. 68:280-300.

Gianinazzi-Pearson, V. 1996. Plant cell responses to arbuscular mycorrhizal fungi: Getting to the roots of the symbiosis. Plant Cell 8:1871-1883.

Hayashi, M., Miyahara, A., Sato, S., Kato, T., Yoshikawa, M., Taketa, M., Hayashi, M., Pedrosa, A., Onda, R., Imaizumi-Anraku, H., Bachmair, A., Sandal, N., Stougaard, J., Murooka, Y., Tabata, S., Kawasaki, S., Kawaguchi, M., and Harada, K. 2001. Construction of a genetic linkage map of the model legume Lotus japonicus using an intraspecific F2 population. DNA Res. 8:301-310.

Imaizumi-Anraku, H., Kawaguchi, M., Koiwa, H., Akao, S., and Syono, K. 1997. Two ineffective-nodulating mutants of Lotus japonicus: Different phenotypes caused by the blockage of endocytotic bacterial release and nodule maturation. Plant Cell Physiol. 38:871-881.

Imaizumi-Anraku, H., Takeda, N., Charpentier, M., Perry, J., Miwa, H., Umehara, Y., Kouchi, H., Murakami, Y., Mulder, L., Vickers, K., Pike, J., Downie, J. A., Wang, T., Sato, S., Asamizu, E., Tabata, S., Yoshikawa, M., Murooka, Y., Wu, G.-J., Kawaguchi, M., Kawasaki, S., Parniske, M., and Hayashi, M. 2005. Plastid proteins crucial for symbiotic fungal and bacterial entry into plant roots. Nature 433:527-531.

Kaló, P., Gleason, C., Edwards, A., Marsh, J., Mitra, R. M., Hirsch, S., Jakab, J., Sims, S., Long, S. R., Rogers, J., Kiss, G. B., Downie, J. A., and Oldroyd, G. E. 2005. Nodulation signaling in legumes requires NSP2, a member of the GRAS family of transcriptional regulators. Science 308:1786-1789.

Kawaguchi, M., Imaizumi-Anraku, H., Koiwa, H., Niwa, S., Ikuta, A., Syono, K., and Akao, S. 2002. Root, root hair, and symbiotic mutants of the model legume Lotus japonicus. Mol. Plant-Microbe Interact. 15:17-26.

Kawaguchi, M., Motomura, T., Imaizumi-Anraku, H., Akao, S., and Kawasaki, S. 2001. Providing the basis for genomics in Lotus japonicus: The accessions Miyakojima and Gifu are appropriate crossing partners for genetic analyses. Mol. Genet. Genomics 266:157-166.

Kawaguchi, M., Pedrosa-Harand, A., Yano, K., Hayashi, M., Murooka, Y., Saito, K., Nagata, T., Namai, K., Nishida, H., Shibata, D., Sato, S., Tabata, S., Hayashi, M., Harada, K., Sandal, N., Stougaard, J., Bachmair, A., and Grant, W. F. 2005. Lotus burttii takes a position of the third corner in the Lotus molecular genetics triangle. DNA Res. 12:69-77.

Kistner, C., Winzer, T., Pitzschke, A., Mulder, L., Sato, S., Kaneko, T., Tabata, S., Sandal, N., Stougaard, J., Webb, K. J., Szczyglowski, K., and Parniske, M. 2005. Seven Lotus japonicus genes required for transcriptional reprogramming of the root during fungal and bacterial symbiosis. Plant Cell 17:2217-2229.

Krusell, L., Krause, K., Ott, T., Desbrosses, G., Krämer, U., Sato, S., Nakamura, Y., Tabata, S., James, E. K., Sandal, N., Stougaard, J., Kawaguchi, M., Miyamoto, A., Suganuma, N., and Udvardi, M. K. 2005 The sulfate transporter SST1 is crucial for symbiotic nitrogen fixation in Lotus japonicus root nodules. Plant Cell 17:1625-1636.

Krusell, L., Madsen, L. H., Sato, S., Aubert, G., Genua, A., Szczyglowski, K., Duc, G., Kaneko, T., Tabata, S., de Bruijn, F., Pajuelo, E., Sandal, N., and Stougaard, J. 2002. Shoot control of root development and nodulation is mediated by receptor-like kinase. Nature 420:422-426.

Kuppusamy, K. T., Endre, G., Prabhu, R., Penmetsa, R. V., Veereshlingam, H., Cook, D. R., Dickstein, R., and VandenBosch, K. A. 2004. LIN, a Medicago truncatula gene required for nodule differentiation and persistence of rhizobial infections. Plant Physiol. 136:3682-3691.

Lévy, J., Bres, C., Geurts, R., Chalhoub, B., Kulikova, O., Duc, G., Journet, E.-P., Ané, J.-M., Lauber, E., Bisseling, T., Dénarié, J., Rosenberg, C., and Debellé, F. 2004. A putative $\mathrm{Ca} 2+$ and calmodulin-dependent protein kinase required for bacterial and fungal symbioses. Science 303:13611364.

Limpens, E., Franken, C., Smit, P., Willemse, J., Bisseling, T., and Geurts, R. 2003. LysM domain receptor kinases regulating rhizobial Nod factorinduced infection. Science 302:630-633.

Madsen, E. B., Madsen, L. H., Radutoiu, S., Olbryt, M., Rakwalska, M., Szczyglowski, K., Sato, S., Kaneko, T., Tabata, S., Sandal, N., and Stougaard, J. 2003. A receptor kinase gene of the LysM type is involved in legume perception of rhizobial signals. Nature 425:637-640.

Mitra, R. M., Gleason, C. A., Edwards, A., Hadfield, J., Downie, J. A., Oldroyd, G. E. D., and Long, S. R. 2004. A Ca ${ }^{2+} /$ calmodulin-dependent protein kinase required for symbiotic nodule development: Gene identification by transcript-based cloning. Proc. Natl. Acad. Sci. U.S.A. 101:4701-4705.
Mitra, R. M., and Long, S. R. 2004. Plant and bacterial symbiotic mutants define three transcriptionally distinct stages in the development of the Medicago truncatula/Sinorhizobium meliloti symbiosis. Plant Physiol. 134:595-604.

Nakamura, Y., Kaneko, T., Asamizu, E., Kato T., Sato, S., and Tabata, S. 2002. Structural analysis of a Lotus japonicus genome. II. Sequence features and mapping of sixty-five TAC clones which cover the $6.5-\mathrm{Mb}$ regions of the genome. DNA Res. 9:63-70.

Nishimura, R., Hayashi, M., Wu, G.-J., Kouchi, H., Imaizumi-Anraku, H., Murakami, Y., Kawasaki, S., Akao, S., Ohmori, M., Nagasawa, M., Harada, K., and Kawaguchi, M. 2002a. HAR1 mediates systemic regulation of symbiotic nodule development. Nature 420:426-429.

Nishimura, R., Ohmori, M., Fujita, H., and Kawaguchi, M. 2002b. A Lotus basic leucine zipper protein with a RING-finger motif negatively regulates the developmental program of nodulation. Proc. Natl. Acad. Sci. U.S.A. 99:15206-15210.

Novák, K., Pešina, K., Nebesářová, J., Škrdleta, V., Lisá, L., and Našinec, V. 1995. Symbiotic tissue degradation pattern in the ineffective nodules of three nodulation mutants of pea (Pisum sativum L.). Ann. Bot. 76:303-313.

Nukui, N., Ezura, H., and Minamisawa, K. 2004. Transgenic Lotus japonicus with an ethylene receptor gene $\mathrm{Cm}$-ERS1/H7OA enhances formation of infection threads and nodule primordia. Plant Cell Physiol. 45:427435.

Nutman, P. S. 1952. Studies on the physiology of nodule formation. III. Experiments on the excision of root-tip and nodules. Ann. Bot. 13:81102.

Oldroyd, G. E. D., and Downie, J. A. 2004. Calcium, kinases and nodulation signalling in legumes. Nat. Rev. Mol. Cell Biol. 5:566-576.

Ott, T., van Dongen, J. T., Günther, C., Krusell, L., Desbrosses, G., Vigeolas, H., Bock, V., Czechowski, T., Geigenberger, P., and Udvardi, M. K. 2005 Symbiotic leghemoglobins are crucial for nitrogen fixation in legume root nodules but not for general plant growth and development. Curr. Biol. 15:531-535.

Radutoiu, S., Madsen, L. H., Madsen, E. B., Felle, H. H., Umehara, Y., Grønlund, M., Sato, S., Nakamura, Y., Tabata, S., Sandal, N., and Stougaard, J. 2003. Plant recognition of symbiotic bacteria requires two LysM receptor-like kinase. Nature 425:585-592.

Sagan, M., Huget, T., and Duc, G. 1994. Phenotypic characterization and classification of nodulation mutants of pea (Pisum sativum L.). Plant Sci. 100:59-70

Sandal, N., Krusell, L., Radutoiu, S., Olbryt, M., Pedrosa, A., Stracke, S., Sato, S., Kato, T. Tabata, S., Parniske, M., Bachmair, A., Ketelsen, T., and Stougaard, J. 2002. A genetic linkage map of the model legume Lotus japonicus and strategies for fast mapping of new loci. Genetics 161:1673-1683

Sandal, N., Petersen, T. R., Murray, J., Umehara, Y., Karas, B., Yano, K., Kumagai, H., Yoshikawa, M., Saito, K., Hayashi, M., Murakami, Y., Wang, X., Hakoyama, T., Imaizumi-Anraku, H., Sato, S., Kato, T., Chen, W., Hossain, Md. S., Shibata, S., Wang, T. L., Yokota, K., Larsen, K., Kanamori, N., Madsen, E., Radutoiu, S., Madsen, L. H., Radu, T. G., Krusell, L., Ooki, Y., Banba, M., Betti, M., Rispail, N., Skøt, L., Tuck, E., Perry, J., Yoshida, S., Vickers, K., Pike, J., Mulder, L., Charpentier, M., Müller, J., Ohtomo, R., Kojima, T., Ando, S., Marquez, A. J., Gresshoff, P. M., Harada, K., Webb, J., Hata, S., Suganuma, N. Kouchi, H., Kawasaki, S., Tabata, S., Hayashi, M., Parniske, M., Szczyglowski, K., Kawaguchi, M., and Stougaard, J. 2006. Genetics of symbiosis in Lotus japonicus: Recombinant inbred lines, comparative genetic maps and map position of 35 symbiotic loci. Mol. PlantMicrobe Interact. 19:80-91.

Sato, S., Kaneko, T., Nakamura, Y., Asamizu, E., Kato, T., and Tabata, S. 2001. Structural analysis of a Lotus japonicus genome. I. Sequence features and mapping of fifty-six TAC clones which cover the $5.4 \mathrm{Mb}$ regions of the genome. DNA Res. 8:311-318.

Schauser, L., Handberg, K., Sandal, N., Stiller, J., Thykjær, T., Pajuelo, E., Nielsen, A., and Stougaard, J. 1998. Symbiotic mutants deficient in nodule establishment identified after T-DNA transformation of Lotus japonicus. Mol. Gen. Genet. 259:414-423.

Schauser, L., Roussis, A., Stiller, J., and Stougaard, J. 1999. A plant regulator controlling development of symbiotic root nodules. Nature 402:191-195

Smit, P., Raedts, J., Portyanko, V., Debellé, F., Gough, C., Bisseling, T., and Geurts, R. 2005. NSP1 of the GRAS protein family is essential for rhizobial Nod factor-induced transcription. Science 308:1789-1791.

Stracke, S., Kistner, C., Yoshida, S., Mulder, L., Sato, S., Kaneko, T., Tabata, S., Sandal, N., Stougaard, J., Szczyglowski, K., and Parniske, M. 2002. A plant receptor-like kinase required for both bacterial and fungal symbiosis. Nature 417:959-962.

Szczyglowski, K., Shaw, R. S., Wopereis, J., Copeland, S., Hamburger, D., Kasiborski, B., Dazzo, F. B., and de Bruijn, F. J. 1998. Nodule organo- 
genesis and symbiotic mutants of the model legume Lotus japonicus. Mol. Plant-Microbe Interact. 11:684-697.

Tansengco, M. L., Hayashi, M., Kawaguchi, M., Imaizumi-Anraku, H., and Murooka, Y. 2003. crinkle, a novel symbiotic mutant that affects the infection thread growth and alters the root hair, trichome, and seed development in Lotus japonicus. Plant Physiol. 131:1054-1063.

Tansengco, M. L., Imaizumi-Anraku, H., Yoshikawa, M., Takagi, S., Kawaguchi, M., Hayashi, M., and Murooka, Y. 2004. Pollen development and tube growth are affected in the symbiotic mutant of Lotus japonicus, crinkle. Plant Cell Physiol. 45:511-520.

Tsyganov, V. E., Morzhina, E. V., Stefanov, S. Y., Borizov, A. Y., Lebsky, V. K., and Tikhonovich, I. A. 1998. The pea (Pisum sativum L.) genes sym33 and sym40 control infection thread formation and root nodule function. Mol. Gen. Genet. 259:491-503.

Tsyganov, V. E., Voroshilova, V. A., Kukalev, A. S., Azarova, T. S., Yakobi, L. M., Borisov, A. Y., and Tikhonovich, I. A. 1999. Pisum sativum L. genes Sym14 and Sym35 control infection thread growth initiation during the development of symbiotic nodules. Russ. J. Genet. 35:284-291.

Tsyganov, V. E., Voroshilova, V. A., Priefer, U. B., Borisov, A. Y., and Tikhonovich, I. A. 2002. Genetic dissection of the initiation of the in- fection process and nodule tissue development in the Rhizobium-pea (Pisum sativum L.) symbiosis. Ann. Bot. 89:357-366.

Turgeon, B. G., and Bauer, W. D. 1982. Early events in the infection of soybean by Rhizobium japonicum. Time course and cytology of the initial infection process. Can. J. Bot. 60:152-161.

van Brussel, A. A. N., Tak, T., Boot, K. J. M., and Kijne, J. W. 2002. Autoregulation of root nodule formation: Signals of both symbiotic partners studied in a split-root system of Vicia sativa subsp. nigra. Mol. PlantMicrobe Interact. 15:341-349.

Vasse, J., de Billy, F., and Truchet, G. 1993. Abortion of infection during the Rhizobium meliloti-alfalfa symbiotic interaction is accompanied by a hypersensitive reaction. Plant J. 4:555-566.

Veereshlingam, H., Haynes, J. G., Penmetsa, R. V., Cook, D. R, Sherrier, D. J., and Dickstein, R. 2004. nip, a symbiotic Medicago truncatula mutant that forms root nodules with aberrant infection threads and plant defense-like response. Plant Physiol. 136:3692-3702.

Wopereis, J., Pajuelo, E., Dazzo, F. B., Jiang, Q., Gresshoff, P. M., de Bruijn, F. J., Stougaard, J., and Szczyglowski, K. 2000. Short root mutant of Lotus japonicus with a dramatically altered symbiotic phenotype. Plant J. 23:97-114. 